\title{
OVARIAN INACTIVITY IN DAIRY COWS: THE INCIDENCE, CAUSES AND A TRIAL OF TREATMENT
}

\author{
A. Karen ${ }^{1}$, B. Heleil' ${ }^{1}$, A. Nasef ${ }^{2}$, B. Serur ${ }^{1}$ \\ 1Department of Theriogenology, Faculty of Veterinary Medicine, Kafrelsheikh University. \\ 2General Authority for Veterinary Services, Gharbia Directorate.
}

\begin{abstract}
The aim of the present study was to investigate the incidence and causes of ovarian inactvity and evaluate the efficacy of single administration of GnRH for treatment of inactive ovaries in dairy cows. Two experiments were carried out to fulfill the aims of the study. In experiment 1, 122 cows which had not shown estrous signs $\geq$ 45 after calving were examined twice by transrectal ultrasonography at a 7-10 day interval to diagnose the causes of anestrous and assess the incidence of ovarian inactivity. In Experiment 2, blood samples were collected from 30 cows with ovarian inactivity and 13 cyclic cows to comapre the blood concentration of insuline, glucose, calcium and phosphorus between the two types of cows. Cows $(n=30)$ suffering from ovarian inactivity were treated with either $500 \mu \mathrm{g}$ gonadorelin acetate intramuscular $(G 1 ; n=20)$ or saline intramuscular (G2; $n=10$ ). The ovaries of cows in G1 and G2 were examined by transrectal palpation twice before and twice after the treatment at a week interval. After transrectal palpation, blood samples were collected from cows for assessment of progesterone, insulin and glucose. Also the cows were observed for estrous signs and those cows showed estrus were inseminated. In Experiment 1, silent or unobserved estrus (47.5\%), inactive ovaries (41\%), cystic ovaries (9\%) and pyometra (2.5\%) were the reasons of anestrous in the
\end{abstract}


studied dairy cows. In Experiment 2, there were significant differences in the blood concentrations of insulin $(P<0.0005)$ and glucose $(P<$ $0.01)$ between cyclic and non-cyclic cows. On the other hand, there were non-significant differences in the blood concentrations of calcium and phosphorus between the cyclic and non-cyclic cows. Estrus induction rates within 14 days after treatment were significantly $(P<0.05)$ higher in G1 $(60 \%)$ than in G2 $(10 \%)$. Seven of 12 cows (58.3\%) responded to administration of GnRH in $G 1$ and the responded cow (1/1) in G2 were pregnant at Day 60 after AI. In conclusion, ovarian inactivity is the main reason of postpartum anestrous in dairy cows. Lower level of insulin and glucose might be among the reasons of ovarian inactivity. Single administration of $\mathrm{GnRH}$ is reasonably effective for treatment of ovarian inactivity in dairy cows.

\section{INTRODUCTION}

Anestrus in abroad term indicates the lack of expression of estrus signs despite efficient estrus detection (Peter et al., 2009). The forms of clinical anestrus are inactive ovaries silent ovulation cystic ovarian degeneration and persistent CL (Mwaanga and Janowski, 2000).

Ovarian inactivity is the most common cause $(49,2 \%)$ of postpartum ovarian dysfunctions and representing 94\% of delayed postpartum ovarian cyclicity (Opsomer et al., 1998). Season of calving, calving problems, extended length of of the previous dry period, severe negative energy balance, and health problems, i.e. ketosis, during the first month of lactation increased the risk of delayed postpartum ovarian cyclicity (Opsomer et al., 2000).

Several treaments are adopted for treatment of ovarian inactivity in cows including administration of single or multiple dosages of $\mathrm{GnRH}$ Kafrelsheikh Vet. Med. J. Vol. 8 No. 2 (2010) 
(Dhoble and Gupta., 1986, Hussien et al., 1992), GnRH in conjunction with PGF2 $\alpha$ (Twagiramungu et al., 1992), ovsynch (Stevenson et al., 2008) and doublesynch (Öztürk et al., 2010) protocols and controlled intravaginal progesterone releasing devices alone or in conjunction with estradiol benzoat, PGF22 $\alpha$, eCG or ovsynch protocol (Xu et al., 1997, Lopez-Gatius et al., 2001; Pursley et al., 2001, Rhodes et al., 2002). Although exogenous progestagens are considered the most appropriate therapy for inactives ovaries in dairy cows (Peter et al., 2009), these intravaginal progesterone devices are not permissible in everywhere. The aim of the present study was to investigate the the incidence of causes of postpartum anestrous in dairy cows and evaluate the efficacy of single administration of GnRH for treatment of inactive ovaries in dairy cows.

\section{MATERIALS AND METHODS}

\subsection{Experiment 1:}

The aim of Experiment 1 was to investigate the causes of postpartum anestrous and to determine the incidence of each cause in Holstein-Friesian cows.

\subsubsection{Animals:}

One hundred-twenty two Holstein-Friesian cows which had not shown estrus signs $\geq 45$ days postpartum were considered as anestrous (Lamming and Darwash 1998) and included in Experiment 1 during the period from May 2006 to August 2009. They were housed in open yards with shelters and were milked three times per day by milking machine. The estrus was observed in the animals by experienced person 4 times daily for 30 minutes. Cows were fed a ration containing protein: 18\%, 
energy: $1.6 \mathrm{k}$ calorie /kg dry , moisture $60 \%$ and 40\% dry matter. Each animal eats $8 \mathrm{~kg}$ concentrate, $3 \mathrm{~kg}$ hay, $3 \mathrm{~kg}$ wheat straw and $3 \mathrm{~kg}$ silage per day. The mean ( \pm SD) parity, milk yield and days in milk of the animals were $2.21 \pm 1.64,33.09 \pm 7.83 \mathrm{Kg}$ and $70.34 \pm 29.85$ days, respectively.

\subsubsection{Ultrasonography:}

The anestrous cows were examined twice at a 7-10 day interval by transrectal ultrasonography $(5 \mathrm{MHz}$ endorectal linear transducer, Ultrascan 1700, Noveko Echographs Inc., Quebec, Canada) in order to diagnose the cause of anestrous. Ovarian cysts were identified as smooth follicle-like fluctuating structures, larger than $2.4 \mathrm{~cm}$ in the diameter and persist for more than 7-10 days in the absence or presence of CL (Hanzen, et al., 2000). Follicular cyst appeared as anechoic structure with thin $(<3 \mathrm{~mm})$ or thick $(\geq 3 \mathrm{~mm})$ echogenic wall in follicle theca cyst and luteinized cyst, respectively (Carroll, et al., 1990). A mature CL appeared as a grayish echogenic area with a line of demarcation between it and ovarian stroma (Kastelic, et al., 1990). Anestrous cows which had neither corpus luteum nor cystic structure in two consecutive examinations per rectum at a 7-day interval were diagnosed as having inactive ovaries (Markusfeld, 1987). The ovarian inactivity appeared by the ultrasonography as a small structure, the cortex appeared hyper-echognetic and free from the corpus luteum and could be differentiated from the hypoechogenic medulla (Boyed 1995). Ultrasonographic diagnosis of pyometra was based on detection of high volume echogenic uterine content with CL on the ovaries (Kahn and Leidl, 1989).

\subsection{Experiment 2:}


The aim of Experiment 2 was to compare the blood level of insulin, glucose, calcium and phosphorus between cyclic and acyclic (inactive ovaries) cows and to evaluate the efficacy of administration of GnRH analogue for inducing estrus in cows affected with inactive ovaries.

\subsubsection{Animals:}

Forty-three Holstein-Friesian cows (30 cows affected with inactive ovaries and 13 cows were cyclic) which had calved more than 45 days were used in this experiment. The body condition scores of the cows were estimated by the same operator according to (Ferguson, et al., 1994). The management of the animals was as that mentioned in Experiment 1. The mean ( \pm S.D.) parity, body condition score, milk yield and days in milk in cyclic cows were $3.08 \pm 1.18$, $3.65 \pm 0.43,30.77 \pm$ $4.96 \mathrm{Kg}$ and $73.23 \pm 36.68$ days, respectively and in cows with ovarian inactivity were $3.80 \pm 1.30,3.78 \pm 0.44,29.67 \pm 10.17 \mathrm{Kg}$ and $144.67 \pm$ 82.87 days.

\subsubsection{Palpation per rectum:}

The ovaries of all cows were examined by transrectal palpation. Those animals which had no corpus luteum on the ovaries were reexamined 7-10 day later to confirm the ovarian inactivity. Also, cows suffering from ovarian inactivity were examined 2 times after the treatment at a 7- day interval in order to detect the response to the treatment.

\subsubsection{Treatment:}

$\overline{\text { Kafrelsheikh Vet. Med. J. Vol. } 8 \text { No. } 2 \text { (2010) }}$ 
Cows suffering from smooth inactive ovaries were randomly divided into two groups. Cows in Group $1(n=20)$ were administrated 5 ml GONAbreed®(Gonadorelin acetate, $100 \mu \mathrm{g} / \mathrm{mL}$; Parnell Laboratories New Zealand Ltd, New Zealand) intramuscular. Cows in Group 2 ( $\mathrm{n}=10)$ were administrated $5 \mathrm{ml}$ saline intramuscular and considered as control group.

\subsubsection{Blood sampling:}

Immediately after transrectal palpation, 4 blood samples were taken at 7 day-intervals from jugular vein of acyclic (ovarian inactivity) cows into vacutainer tubes for assessment of insulin, glucose, calcium (Ca) and phosphorus (P). The first blood sampling was 7 days before treatment (Day -7) and the second sampling was just before treatment (Day 0). The third and fourth blood samplings were at Day 7 and 14 after treatment, respectively. In addition, blood samples were taken once from cyclic cows to compare the concentration of insulin, glucose, calcium (Ca) and phosphorus $(\mathrm{P})$ with those of acyclic cows at Day -7 . Since there was a significant difference in days in milk (73.23 \pm 36.68 vs.144.67 \pm 82.87 days) between cyclic and acyclic cows and thereby to avoid the effect of days in milk on the blood concentration of insulin, glucose, Ca and P, the data of 16 acyclic cows which had days in milk (89.0 \pm 31.70$)$ similar to that of cyclic cows were used in the comparison. The blood samples were placed in an ice box and transferred to laboratory. Blood samples were centrifuged at 1500 r.p.m. for 30 minutes. The harvested sera were stored at $-20^{\circ} \mathrm{C}$ till hormonal and macro-elements analysis.

\subsubsection{Hormonal, glucose and macro-elements assays:}




\section{a. Progesterone radioimmunoassay:}

Estimation of P4 was carried out to confirm ovarian inactivity (before treatment) and the response to treatment (after treatment). It was measured using radioimmunoassay diagnostic kits (Diagnostic Products Incorporation, Los Angles, USA) according to Gautary et al. (1981). The sensitivity of P4 assay was $0.2 \mathrm{ng} / \mathrm{ml}$. The intra assay coefficient of variation of low P4 (0.81 ng/mL), medium (3.9 ng/mL) and high concentration $(7.2 \mathrm{ng} / \mathrm{mL})$ were $16 \%, 8.1 \%$ and $7.2 \%$, respectively. The inter-assay coefficients of variation of the low, medium and high P4 concentration were $16 \%, 7.9 \%$ and $5.8 \%$, respectively.

\section{b. Insulin assay:}

It was measured by using enzyme immuno-assay (EIA 2935, DRG International, USA) according to Perryy and Grossman (1997). The sensitivity of insulin assay was $1.76 \mu \mathrm{U} / \mathrm{ml}$. The intra assay coefficient of low insulin $(17.45 \mu \mathrm{U})$ and high concentration $(66.43 \mu \mathrm{U})$ were $2.6 \%$ and $1.79 \%$ respectively. The inter-assay coefficients of variation low $(17.36 \mu \mathrm{U})$ and high insulin concentrations $(66.9 \mu \mathrm{U})$ were $2.88 \%$ and $5.99 \%$, respectively.

\section{c. Glucose, calcium and phosphorous:}

Glucose, calcium and phosphorous were measured in blood serum by spectrophotometer using kits of Europe contact (Steinocker 20, Aichwald, Germany).

\subsubsection{Reproductive management and fertility:}


Cows of GnRH-treated and control groups were observed for estrous signs four times throughout the day. Estrus induction rate was determined based on visual observation of estrus and confirmed by change in blood P4 concentration. Cows were assumed to resume ovarian cyclicity when P4 level was $\geq 1 \mathrm{ng} / \mathrm{mL}$ (Lopez-Gatius et al., 2001). Cows were inseminated approximately 8-10 h after the first signs of estrus, Pregnancy diagnosis was made by transrectal palpation at 60 days post-insemination and the conception rate was calculated.

\subsubsection{Statistical Analyses:}

Student $t$-test was used to compare the means of insulin, glucose, $\mathrm{Ca}$ and $\mathrm{P}$ concentration between cyclic and acyclic cows. Paired $t$-test was used to compare means of insulin and glucose concentration before and after treatment. Fisher's exact test was used to compare the proportions of estrus induction rate and conception rate between $\mathrm{GnRH}$ treated and saline groups (Petrie and Watson, 1999).

\section{RESULTS}

\subsection{Experiment 1:}

\subsubsection{Causes of anestrous:}

A total of 122 cows were diagnosed as anestrous. Silent or unobserved estrus (47.5\%), the inactive ovaries (41\%), cystic ovaries (9\%) and pyometra (2.5\%) were the reasons of anestrous in the studied dairy cows (Table 1). 
A. Karen et., al.

Table (1): Number (No.) and frequency (\%) of the causes of anestrous in dairy cows.

\begin{tabular}{||l||c|c||}
\hline \multirow{2}{*}{\multicolumn{1}{|c||}{ Causes of anestrous }} & \multicolumn{2}{c||}{ Number and frequency } \\
\cline { 2 - 3 } & No & \% \\
\hline \hline Silent or unobserved estrus & 58 & 47.5 \\
\hline Inactive ovaries & 50 & 41 \\
\hline Cystic ovaries & 11 & 9 \\
\hline Pyometra & 3 & 2.5 \\
\hline \hline Total & $\mathbf{1 2 2}$ & $\mathbf{1 0 0}$ \\
\hline \hline
\end{tabular}

\subsection{Experiment 2:}

There were significant differences in the blood concentrations of insulin $(\mathrm{P}<0.0005)$ and glucose $(\mathrm{P}<0.01)$ between cyclic and non-cyclic cows. On the other hand, there were non-significant differences in the blood concentrations of calcium and phosphorus between the cyclic and non-cyclic cows (Table 2).

Table (2): Concentrations (Mean \pm S.D.) of insulin, glucose, calcium (Ca) and phosphorus (P) in cyclic and acyclic cows.

\begin{tabular}{|c||c||c||}
\hline Parameters & Cyclic cows $(\mathbf{n}=13)$ & Acyclic cows $(\mathbf{n}=16)$ \\
\hline \hline Insulin $(\mu \mathrm{U} / \mathrm{mL})$ & $27 \pm 5.42^{\mathrm{a}}$ & $18 \pm 3.34^{\mathrm{b}}$ \\
\hline Glucose $(\mathrm{mg} / \mathrm{dl}) *$ & $80.71 \pm 1.07^{\mathrm{c}}$ & $70.32 \pm 5.44^{\mathrm{d}}$ \\
\hline $\mathrm{Ca}(\mathrm{mg} / \mathrm{dl})$ & $12.05 \pm 1.37$ & $11.66 \pm 1.52$ \\
\hline P (mg/dl) & $8.23 \pm 0.66$ & $7.84 \pm 1.14$ \\
\hline
\end{tabular}

*Number of cyclic and acyclic cows were 10 and 6, respectively.

${ }^{\text {a,b }} \mathrm{P}<0.0005,{ }^{\mathrm{c}, \mathrm{d}} \mathrm{P}<0.01$

$\overline{\overline{\text { Kafrelsheikh Vet. Med. J. Vol. } 8 \text { No. } 2 \text { (2010) }}}$ 


\subsubsection{Response to the treatments:}

Twelve of 20 acyclic cows (60\%) showed estrus within two weeks ( 4 cows within the first and 8 within the $2^{\text {nd }}$ week) after administration of GnRH in G1. On the other hand, one of ten acyclic cows (10\%) showed estrus (within the first week) after administration of saline in G2. There was a significant difference $(\mathrm{P}<0.05)$ in the proportion of responding cows (showing estrus) between G1 and G2. Seven of 12 cows (58.3\%) responded to administration of $\mathrm{GnRH}$ in $\mathrm{G} 1$ and the responded cow (1/1) in G2 were pregnant at Day 60 after AI (Table 3).

Table (3): Estrus induction rate and conception rate in cows with inactive ovaries treated with GnRH (G1) or with saline (G2).

\begin{tabular}{|c|c|c|c|c|}
\hline \multirow{3}{*}{ Groups } & \multicolumn{3}{|c|}{ Estrus induction rate } & \multirow{3}{*}{ Conception rate } \\
\hline & \multicolumn{3}{|c|}{ Weeks (W) after treatment } & \\
\hline & W1 & W2 & Total & \\
\hline $\mathrm{G} 1(\mathrm{n}=20)$ & $4 / 20(20 \%)$ & $8 / 20(40 \%)$ & $12 / 20^{\mathrm{a}}(60 \%)$ & $7 / 12(58.3 \%)$ \\
\hline $\mathrm{G} 2(\mathrm{n}=10)$ & $1 / 10(10 \%)$ & 0/10 (1\%) & $1 / 10^{\mathrm{b}}(10 \%)$ & $1 / 1(100 \%)$ \\
\hline
\end{tabular}

Before treatment, the average blood concentrations of insulin was non-significantly different between G1 and G2. However, it was significantly $(\mathrm{P}<0.05)$ higher in $\mathrm{G} 1$ than that of $\mathrm{G} 2$ after treatment (Table 6). In cows responding to the administration of $\mathrm{GnRH}$, the average blood concentrations of insulin after treatment was significantly ( $\mathrm{P}<0.01$ ) higher than that before the treatment. However, a nonsignificant increase was observed in cows not responding to $\mathrm{GnRH}$ administration (Table 4). The averages glucose concentrations were similar in cows of G1 and G2 before and after treatment (Fig 1). 
A. Karen et., al.

Table (4): Concentration of (Mean \pm S.D.) of insulin in GnRH- and salinetreated animals and responding and non responding animals before and after treatment.

\begin{tabular}{|c|c|c|}
\hline \multirow{3}{*}{ Grouping of the animals } & \multicolumn{2}{|c|}{ Insulin concentrations $(\mu \mathrm{U} / \mathrm{mL})$} \\
\hline & \multicolumn{2}{|c|}{ Treatment } \\
\hline & Before & After \\
\hline GnRH-treated cows $(n=20)$ & $17.45 \pm 2.90^{\mathrm{a}}$ & $19.58 \pm 2.14^{\mathrm{b}, \mathrm{c}}$ \\
\hline Responding ( $\mathrm{n}=12$ ) & $17.92 \pm 3.13^{\mathrm{a}}$ & $20.29 \pm 1.99^{b}$ \\
\hline Non-responding $(\mathrm{n}=8)$ & $16.81 \pm 2.59$ & $18.5 \pm 1.98$ \\
\hline Saline-treated cows $(n=10)$ & $17 \pm 3$ & $17 \pm 2^{d}$ \\
\hline Responding ( $\mathrm{n}=1)$ & 20.5 & 15 \\
\hline Non-responding ( $\mathrm{n}=9$ ) & $16.06 \pm 2.47$ & $17.56 \pm 2.11$ \\
\hline
\end{tabular}

${ }^{\mathrm{a}, \mathrm{b}} \mathrm{P}<0.01$; ${ }^{\mathrm{c}, \mathrm{d}} \mathrm{P}<0.05$

Fig.(1): Mean blood glucose and insulin concentrations in cow with ovarian inactivity before and after treatment with GnRH(G1)or saline(G2).

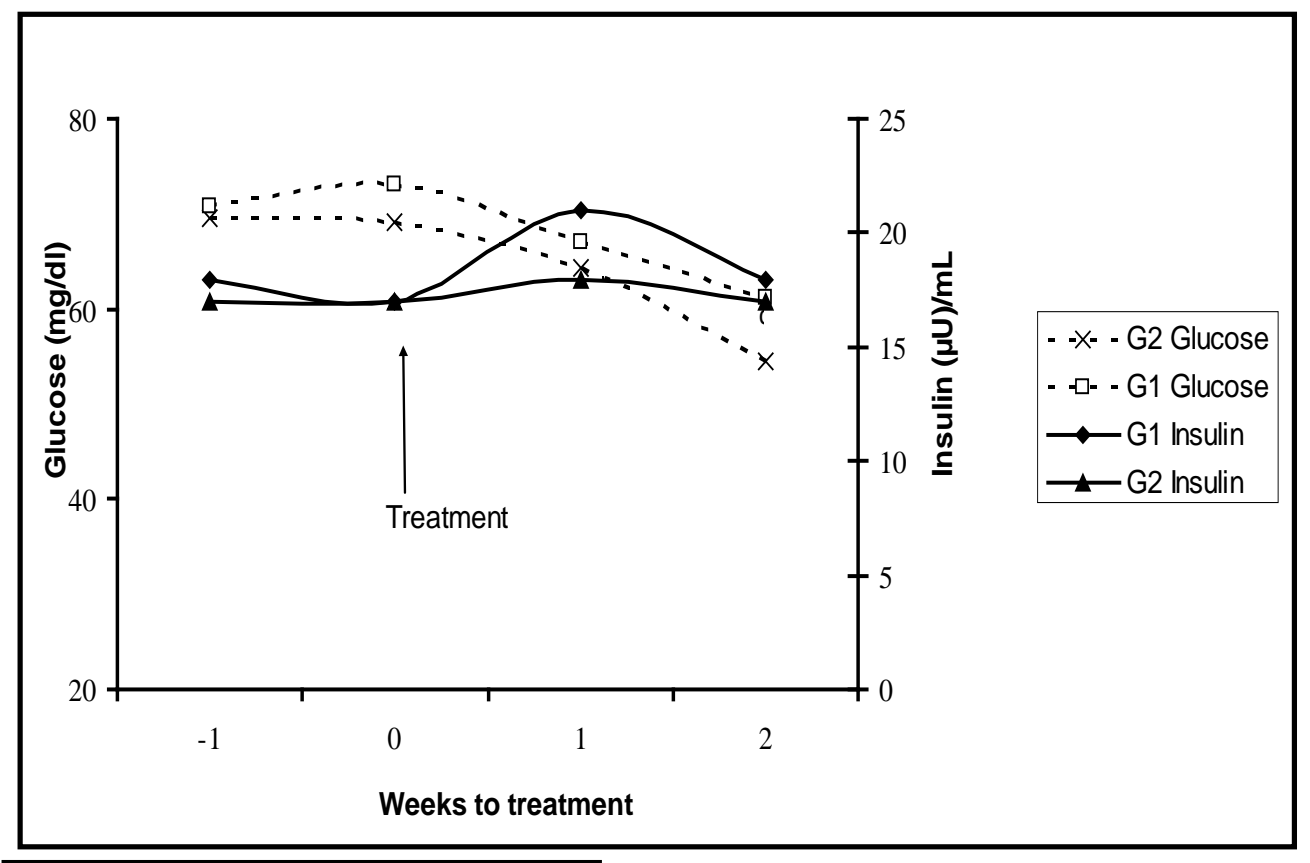

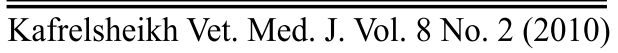


Fig. (2): Blood progesterone (Mean \pm S.E.M; ng/mL) concentrations in treated (T) and control groups (C).

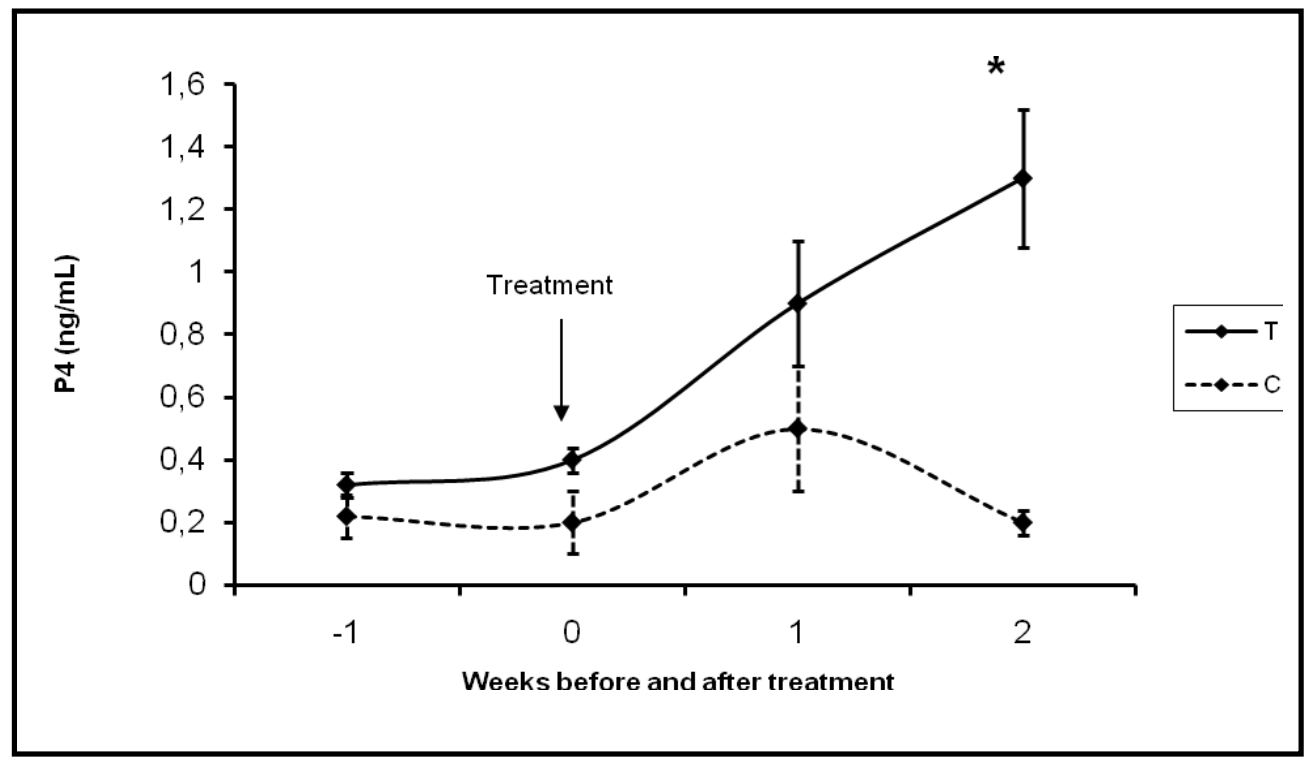

$* \mathrm{P}<0.005$

Averages blood P4 concentrations in G1 and G2 were similar before treatment.However, the average blood progesterone concentrations increased in cows of G1 after administration of GnRH and a significant difference $(\mathrm{P}<0.005)$ was observed between cows of G1 and G2 at Week 2 after treatment (Fig.2).

\section{DISCUSSION}

In our study, $47.5 \%$ (58/122) of anestrous cows suffered from silent heat or unobserved estrous. Similar results (40-59\%) were reported in other studies (Kalis and Van de Wiel, 1980; Claus et al., 1983). Also, the percentage of anestrous cows (41\%) suffering from of ovarian inactivity was similar to that reported in an study in which ovarian inactivity represented $49,2 \%$ of postpartum ovarian dysfunctions $\overline{\overline{\text { Kafrelsheikh Vet. Med. J. Vol. } 8 \text { No. } 2(2010)}}$ 
(Opsomer et al., 1998). Regarding ovarian cysts, its incidence in our study is within the range (6 to 30 \%) reported in dairy cows (Garveric, 1997), considering that $80 \%$ of cow with ovarian cysts experience anestrous (Garveric, 2007).

Recently it has been demonstrated that delaying the first postpartum ovulation is associated with a lower circulating insulin concentration in high milk yield cows (Gong et al., 2002). Also, a case-control study demonstrated lower circulating concentrations of glucose and thyroxin and higher concentrations of urea in anovulatory anestrous cows, compared with contemporary cows that had resumed estrous cycles (McDougall et al., 1993). Theses findings are in agreement with that of the present study, whereas the insulin (27 vs. $18 \mu \mathrm{IU}, \mathrm{P}<0.0005)$ and glucose (80.7 vs. $70.32 \mathrm{mg} / \mathrm{dl}, \mathrm{P}<0.01$ ) concentrations were significantly higher in cyclic than acyclic cows. It is likely that increased insulin concentrations promoted the differentiation and maturation of dominant follicle, thereby increasing the chance of these dominant follicles ovulating in response of LH surge (Beam and Butler, 1999). It is demonstrated that, glucose availability influences both tonic and surge modes of LH secretion through its role in modulating GnRH (Diskin et al., 2003).

The blood glucose and insulin concentrations obtained in the present study are similar to that reported in Friesian cows between Days 30 to 90 postpartum (Accorsi et al., 2005, Tanaka et al., 2008).

In our study, single administration of GnRH to cows with ovarian inactivity induced estrous in a significant higher percentage of cows (60\% vs. 10\%) when compared to cows received saline. A lower 
response rate (ovulation and expression of estrus signs) (22.4\%) to GnRH administration was reported in Hariana crossed with Holstein, Friesian, Brown Swiss or Jersey half-breed crosses (Dhoble and Gupta, 1986). In contrast, a higher response rate (inducing cyclicity; 91.7\%) was reported 6 days after administration of $\mathrm{GnRH}$ to acyclic beef cows (Twagiramungu et al., 1992) however, non of cows responded to GnRH showed signs of estrus. The difference in the response rate among studies might be attributed to the difference in experimental designs, the breed, percentage of cows having a dominant follicle at the time of GnRH administration and the postpartum interval (Rhodes et al., 2003, LopezGatius et al., 2008, Peter et al.,2009).

The interesting finding in the present study is that the average blood insulin concentration was significantly higher in cows of G1 than that in cows of G2 after administration of GnRH or saline, respectively. An effect on insulin might have occurred after administration of GnRH. To the best of our knowledge, there is no literature dealing with effect of $\mathrm{GnRH}$ on insulin. Further studies are required to investigate the relationship between GnRH and insulin. The significant increase of blood insulin only in GnRH-responded cows confirms our finding concerning increase of insulin in cyclic than in acyclic cows and give a support to the suggested role of insulin for growth of the follicle and enhancing the first postpartum ovulation (Beam and Butler, 1999; Gong et al., 2002).

In conclusion, ovarian inactivity is the main reason of postpartum anestrous in dairy cows. Lower level of insulin and glucose might be among the reasons of ovarian inactivity. Single administration of GnRH is reasonably effective for treatment of ovarian inactivity in dairy cows. 


\section{REFERENCES}

- Accorsi, P.A., Govoni, N., Gaiani, R., Pezzi, C., Seren, E., Tamanini, C., (2005): Leptin, GH, PRL, insulin and metabolic parameters throughout the dry period and lactation in dairy cows. Reprod. Dom. Anim., 40:217-223.

- Beam, S.W., and Butler, W.R. (1999): Energy balance effects on follicular development and first ovulation in postpartum cows. Reprod. Fertil. Suppl. 54:411-424.

- Boyd, J.S., (1995): Real-time diagnostic ultrasound in bovine reproduction In: Veterinary ultrasonography, P. J. Goddard, CAB, International Wallingford Oxon, 108SE, U.K., pp.: 233-255.

- Carroll, D.J., Pierson, R.A., Hauser, E.R., Grummer, R.R., Combs, D.K. (1990): Variability of ovarian structures and plasma progesterone profiles in dairy cows with ovarian cysts. Theriogenology, 34:349-70.

- Claus R., Kary, H., Zwiaur, D., Von Butler I., Pirchner, F., Rattenberger, E., (1983): Analysis of factors influencing reproductive performance of the dairy cow by progesterone assay in milk-fat. Br.Vet. J., 139:29-38.

- Dhoble, R.L. and Gupta S.K., (1986): Response to synthetic gonadoliberin (GnRH) in anestrous cows. Theriogenology, 25: 759-765.

- Dhoble, R.L. and Gupta, S.K., (1986): Response to synthetic gondoliberin (GnRH) to in anestrous cows. Theriogenology, 25:759-765.

- Diskin, M.G., Mackey, D.R., Roche, J.F., Sreenan, J.M., (2003). Effect of nutrition and metabolic status on circulating hormones and ovarian follicle development in cattle. Anim. Reprod. Sci., 78: 345-370. 
- Garverick H. A., (1997): Ovarian follicular cysts in dairy cows. J Dairy Sci., 80: 995-1004.

- Garverick, H.A., (2007): Ovarian follicular cysts. In: Large Animal Theriogenology. $2^{\text {nd }}$ edition, pp. 379-382. Youngquist R.S. and Threfall W.R. (eds.), Saunders Elsevier, USA.

- Gautray J.P., de Brux, J., Tajchner, G., Robel, P., Mouren, M., (1981): Clinical investigation of the menstrual cycle. III. Clinical, endometrial, and endocrine aspects of luteal defect. Fertil and Steril., 35:296-303.

- Gong, J.G., Lee, W.J., Garnsworth, P.C., Webb, R. (2002): Effect of dietary induced increase in circulating insulin concentrations during the early postpartum period on reproductive function in dairy cows. Reproduction, 123:419-427.

- Hanzen, C.H., Pieterse, M., Scenczi, O., Drost, M., (2000): Relative accuracy of the identification of ovarian structures in the cow by ultrasonography and palpation per rectum. Vet. Journal, 159:161-170.

- Hussien, M.F., Elits, B.E., Paccamonti, D.l., Younis ,M.Y., (1992): Effect of repeated injections of GnRH on reproductive parameters in postpartum anestrous dairy cows. Theriogenology,37:605-617.

- Kahn,W.and Leidl, W.(1989):Ultrasonic characteristics of pathological conditions of the bovine uterus and ovaries. In: Diagnostic Ultrasound and Animal Reproduction. 1st Ed., pp.37-52, M.M. Taverne and A.H. Willwmse (ed.), Klurwer Academic Publishers. 
- Kalis, C.H.J. and Van de Wiel, D.F.M. (1980): Relationship of clinical examinations to milk progesterone profiles. Proceed. 9th Intern. Congr. Anim. Reprod. \& A.I., June 16-20, Madrid, 2, 125-134.

- Kastelic, J.P., Bergfelt, D.R., Ginther, O.J., (1990): Relationship between ultrasonic assessment of the corpus luteum and plasma progesterone concentration in heifers. Theriogenology, 33:1269-1277.

- Lamming, G. E., and Darwash, A. O., (1998): The use of milk progesterone profiles to characterize components of subfertility in milked dairy cows. Anim. Reprod. Sci., 52:175-190.

- Lopez-Gatius, F., Mirzaei, A., Santolaria, P.,Bech-Sabat, Nogareda, C., Garcia-Ispierto, I., Hanzen, Ch., Yaniz, J.L., (2008): Factors affecting the response to the specific treatment of several forms of clinical anestrus in high producing dairy cows. Theriogenology, 69:1095-1103.

- López-Gatius, F., Santolaria, P., Yániz, J., Rutllant, J., López-Béjar, M., (2001): Persistent ovarian follicles in dairy cows: a therapeutic approach. Theriogenology. 56:649-659.

- Markusfeld, O., (1987): Inactive ovaries in high-yielding dairy cows before service: Aetiology and effect on conception. Vet. Rec., 121: 149-153.

- McDougal, S., Leijnse,P., Day, A.M., Macmillan, K.L., Williamson, N.B., (1993): A case control study of anestrous in New Zealand dairy cows. Pro.N.Z. Soc. Anim. Prod., 53: 101-103.

- Mwaagna, E.S., Janowski T. (2000): Anoestrus in dairy cows: causes, prevalence and clinical forms. Reprod. Domest. Anim., 35: 193-200. 
- Opsomer, G., Grohn, Y.T., Hertl, J., Coryn, M., Deluyker, H., de Kruif. A. (2000): Risk factors for post partum ovarian dysfunction in high producing dairy cows in Belgium: a field study. Theriogenology, 53:641-657.

- Opsomer, G., Coryn, M., Deluyker, H., De Kruif, A., (1998): An analysis of ovarian dysfunction in high-yielding dairy cows after calving based on progesterone profiles. Reprod. Dom. Anim., 33:193204.

- Öztürk, Ö.A., Cirit Ü., Baran A., Ak, K., (2010): Is doublesynnch protocol a new alternative for timed atrificial insemination in anestrous dairy cows. Theriogenology, 73:568-576.

- Perry, L.A. and Grossman, A.B. (1997): The role of the laboratory in the diagnosis of Cushing's syndrome.Ann.Clin.Biochem.34:345-359.

- Peter, A.T., Vos, P.L.A.M., Ambrose, D.J., (2009): Postpartum anestrus in dairy cattle. Theriogenology, 71:1333-1342.

- Petrie, A. and Watson, P. (1999): Statistics for Veterinary and Animal Science. First edition, Blackwell Scince LTD, London.

- Pursley, J. R, Fricke, P. M., Garverick, H. A., Kesler, D. J., Ottobre, J.S., Stevenson, J.S., Wiltbank, M.C., (2001): Improved fertility in non-cycling lactating dairy cows treated with exogenous progesterone during Ovsynch. Midwest Branch ADSA 2001Meeting, Des Moines, IA, 63 (abstract). 
- Rhodes, F. M., Burke, C. R., Clark, B. A., Day, M. L., Macmillan, K. L., (2002): Effect of treatment with progesterone and oestradiol benzoate on ovarian follicular turnover in postpartum anoestrous cows and cows which have resumed oestrous cycles. Anim. Reprod. Sci. 69:139-150

- Rhodes, F. M., McDougal, S., Burke, C. R., Verkerk, G.A., Macmillan, K. L., (2003): Invited review: treatments of cows with an extended postpartum anestrous interval. J. Dairy Sci., 86:1876-1894.

- Stevenson, J. S., Tenhouse, D. E., Krisher, R. L., Lamb, G. C., Larson, J. E, Dahlen, C. R., Pursley, J.R., Bello, N.M., Fricke, P.M., Wiltbank, M.C., Brusveen, D.J., Burkhart, M., Youngquist, R.S., Garverick, H.A., (2008): Detection of anovulation by heatmount detectors and transrectal ultrasonography before treatment with progesterone in a timed insemination protocol. J. Dairy Sci., 29012915.

- Tanaka, T., Arai, M., Ohtani, S., Uemura, S., Kuroiwa, T., Kim, S., Kamomae, H., (2008): Influence of parity on follicular dynamics and resumption of ovarian cycle in postpartum dairy cows. Anim. Reprod. Sci., 108:134-143.

- Twagiramungu, H., Guilbault, L.A., Proulx, J., Dufour, J.J. (1992): Synchronzation of estrus and fertility in beef cattle with two injections of buserelin and prostaglandin. Theriogenology, 38: 1131-1144.

- Xu, Z. Z., Burton, L. J., Macmillan. K. L. (1997): Treatment of postpartum anoestrous dairy cows with progesterone, oestradiol and equine chorionic gonadotrophin. N.Z. Vet. J. 45:205-207. 
خمول المبايض في الأبقار الحلاب :مدى الإصابة ،الأسباب ومحاولة للعلاج

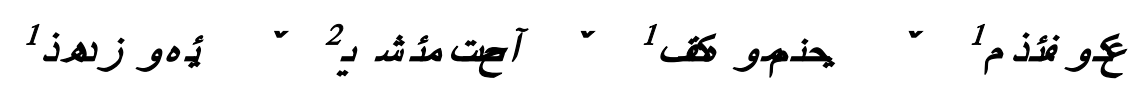
1 قسم التوليد و التناسل و التلقيح الاصطناعى-كلية الطب البيطرى-جامعة كفر الثيخ $2{ }^{2}$

كانت أهداف هذه الدراسة استقصاء مدى الإصابة وأسباب خمول المبايض وكذلك تقييم فاعلية حقن هرمون الحاثة المنثلية-GnRH فى علاج خمول المبايض فى الأبقار الحلاب. أجريت تجربتان لتحقيق أهداف الدراسة. فى التجربة الأولى: تم فحص 122 بقرة هوليشتاين فرزيان لم يظهر عليها علامات الثبق خلال 45 يوم بعد الولادة بجهاز الموجات فوق الصوتية عبر المستقيم مرتين بفاصل زمنى 7 -10 أيام لتشخيص أسباب عدم الثياع وتقييم نسبة الإصابة بخمول المبايض.

في التجربة الثانية: تم جمع عينات دم من 30 بقرة تعانى من خمول المبايض و 13 بقرة ذات مبايض نشطة وأظهرت علامات الثبق خلال 45 يوم بعد الولادة لمقارنة تركيز ألأنسولين والجلوكوز والكالسيوم والفسفور فى الدم بين هذين النوعين من الأبقار. وتم تقسيم 30 بقرة يعانون من خمول المبايض عشوائيا الى مجموعتين: فى المجموعة الأولى تم حقن 20 بقرة 500 ميكروجرام جونادورلين اسيتات فى العضل ، بينما تم حقن 10بقرات بمحلول ملح فى العضل فى المجموعة الثانية (الضابطة). تم فحص مبايض أبقار المجموعتين يدويا عبر المستقيم مرتين قبل ومرتين بعد العلاج بفاصل زمنى 7 أيام. وبعد كل فحص تم جمع عينات دم من الأبقار لتقييم تركيز الأنسولين و البروجسترون والجلوكوز . ولوحظت أيضا الأبقار لعلامات الثبق والأبقار التى أظهرت تلك العلامات تم تلقيحها اصطناعيا. 
في التجربة الأولى كانت أسباب عدم الثياع في الأبقار التي شملتها الدراسة كالتالى: شياع صامت أو شبق أغفله العامل (47.5\%) وخمول المبايض (41\%) وتكيس المبايض (9\%) وتقيح

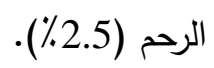

في التجربة الثانية: كان تركيز الأنسولين والجلوكوز في الدم اقل بصورة معنوية (P<0.0005 و على التوالي) فى الأبقار التى تعانى من خمول المبابض عن مثيلاتها ذات المبايض النشطة ولكن لم توجد اختلافات معنوية في تركيزات الكالسيوم والفوسفور فى الدم بين نوعى الأبقار • نسبة إحداث الثبق في غضون 14 يوما بعد العلاج كانت أعلى معنويا ( P<0.05) في المجموعة الأولى (60\%) عن المجموعة الثانية (10\%).

سبع بقرات من أصل 12 بقرة ممن ظهرت عليهج إعراض الثياع فى المجموعة الأولى وبقرة واحدة من المجموعة الثانية التي ظهر عليها أعراض الثياع أصبحوا عشار بعد 60 يوم من التلقيح الاصطناعي.

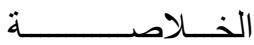

خمول المبايض هو أحد الأسباب الرئيسية لعدم الثياع بعد الولادة وانخفاض مستوى الأنسولين والجلوكوز من بين أسباب خمول المبايض فى الأبقار الحلاب. حقن هرمون الحاثة المنثلية GnRH يمكن ان يكون فعال بثكل معقول لعلاج خمول المبايض في الأبقار الحلاب. 